\title{
PERAN PEMERINTAH SEBAGAI KUNCI UTAMA PENGELOLAAN DANA DESA DI DESA DULUMAI KECAMATAN PAMONA PUSELEMBA KABUPATEN POSO PROPINSI SULAWESI TENGAH
}

\author{
Jeane Mantiri, Cynthia Maria Siwi \\ Program Studi Ilmu Administrasi Negara FIS Unima \\ email: jeanelitha@unima.ac.id
}

\begin{abstract}
This study aims to analyzed and assess the process of using village funds derived since march 2017, adjusted to priority development program by president Joko Widodo called "NAWACITA" on the third point of building the outskirts of Indonesia from the periphery. The village funds distributed annually are itended to improve the economy of rural communities, and make the village as a productive area, considering Indonesia is an agrarian country consisting of many villages. In accordance with the regional autonomy system adopted by the Indonesian government system, villages have an important role to manage the village funds themselves. The project of this research is the use of village funds in Dulumai Village, Pamona Puselemba sub-district, Poso district, Central Sulawesi Province.
\end{abstract}

Keyword: Excellent Product of Rural Area, Management of Village Fund. 


\section{PENDAHULUAN}

Sejak dikeluarkannya Undang-Undang Nomor 6 Tahun 2014 tentang Desa, maka setiap Desa diberikan kewenangan untuk mengatur dan mengembangkan potensi lokalnya. Berdasarkan landasan Hukum tersebut, maka setiap Desa juga memiliki kewenangan dalam hal pemerintahan, melaksanakan pembangunan, mengatur ekonomi dan pendapatan Desa, serta mengatur Rumah Tangganya sendiri. Otonomi daerah dengan sistem Desentralisasi memberikan kewenangan yang bukan hanya sampai pada taraf Kabupaten Kota, melainkan sampai pada sistem pemerintahan di Desa.

Sebagai Negara yang subur dan melimpah akan kekayaan alam, Indonesia tidak seharusnya mengalami kesulitan dalam hal perekonomian. Untuk itu Presiden Joko Widodo membuat terobosan baru dengan menjadikan pembangunan Daerah Pinggiran sebagai salah satu poin utama dalam prioritas pembangunannya yang disebut "NAWACITA" dan masuk dalam Rencana Pembangunan Jangka Menengah Nasional (RPJM Nasional) 2015-2019. Keputusan ini menunjukan keseriusan pemerintah dalam menangani masalah daerah pinggiran, mengingat Indonesia adalah Negara yang terdiri dari beribu-ribu pulau dan sebagian besar masih berstatus pedesaan.

Setiap Desa memiliki kesempatan untuk maju dan berkembang berdasarkan potensi yang dimiliki oleh Desa tersebut baik melalui Sumber Daya Alam, pertanian, perikanan, pariwisata dan lain sebagainya. Karena itu, pemerintah Indonesia sadar betul bahwa Daerah pinggiran atau Desa benarbenar dapat memberikan kontribusi yang besar bagi perkembangan suatu Negara jika pemerintah memberikan kewenangan dan meningkatkan produksi suatu Desa dengan menyalurkan Dana Desa untuk mengembangkan potensi-potensi tersebut.

Ada 4 prioritas utama dari disalurkannya Dana Desa tersebut yaitu Produk Unggulan Kawasan Pedesaan (PRUKADES), BADAN USAHA MILIK
DESA (BUMDes), embung air, dan sarana olahraga Desa. Meninjau dari 4 faktor tersebut, Dana Desa tahun 2017 yang disalurkan sebesar 60 Triliun dengan ratarata setiap Desa mendapat 800 juta, maka tidak dapat dikatakan akan ada 1 diantara 4 program tersebut yang dapat terlewatkan. Dana Desa itu sendiri di salurkan oleh pemerintah secara adil dan merata tanpa terkecuali di seluruh Desa di Indonesia. Satu hal penting yang menjadi kekhawatiran besar ketika diturunkannya Dana Desa tersebut adalah memungkinkan terjadinya kasus penyimpangan atau penyalahgunaan bahkan penggunaan yang tidak tepat sasaran.

Hal yang cukup disayangkan terjadi di salah satu Desa, yaitu Desa Dulumai kecamatan Pamona Puselemba, Kabupaten Poso, Propinsi Sulawesi Tengah. Salah satu program prioritas utama dari penyaluran Dana Desa yaitu Produk Unggulan Kawasan Pedesaan belum terlaksana dengan baik. Desa Dulumai sebagai Desa terkecil di Kecamatan Pamona Puselemba denga luas 7800 Ha yang terdiri dari 2 dusun ini, sebenarnya memiliki potensi pariwisata yang sangat menarik. Mengingat lokasi Desa yang cukup strategis, berada di wilayah pinggiran danau poso dan memiliki kontur wilayah pegunungan, seharusnya membuka peluang besar bagi wisatawan untuk datang mengunjungi objek wisata yang ada di daerah ini jika pemerintah mampu melihat peluang yang besar di Bidang pariwisata dan mengolahnya.

Melihat masalah diatas, dapat dilihat bahwa pemerintah dalam hal ini pemerintah Desa kurang tepat dalam menentukan program pembangunan yang seharusnya dapat meningkatkan potensi dari wilayahnya. Dewasa ini, hampir setiap daerah sedang gencar-gencarnya menaikan potensi sumber daya pariwisata mereka karna bidang pariwisata memberikan kontribusi terbesar bagi pendapatan daerah. Sangat disayangkan sebuah daerah yang sebenarnya sangat berpotensi akan tetapi kurang jeli melihat peluang. 
Jika ditinjau dari pembangunan yang lain, Desa Dulumai sudah memiliki usaha BUMDes yang baik, pembangunan embung air yang sudah terlihat jelas, serta sarana olahraga Desa yang sudah dimanfaatkan baik oleh masyarakat. Cukup mengejutkan dengan fakta bahwa Desa yang dulunya sering dikunjungi oleh wisatawan baik wisatawan lokal Maupun mancanegara tidak mampu menghidupkan kembali objek wisatanya.

Beberapa Daerah sudah disekitaran Danau Poso sudah dapat menjadi contoh keberhasilan di bidang Produk Unggulan Kawasan Pedesaan (PRUKADES). Sebut saja Desa Leboni Yang sudah berhasil memanfaatkan air terjun bertingkat yang dulunya sempat tidak diminati masyarakat karna sudah kurang terawat. Dengan dikeluarkannya Dana Desa 2017 ini, fokus utama produk Unggulan kawasan Pedesaan Desa Leboni di fokuskan pada pengelolaan dan pemeliharaan kembali air terjun. Sehingga dalam waktu singkat dapat meningkatkan perekonomian Desa Leboni.

Jika pemerintah Desa Dulumai mampu mengolah kembali objek wisata yang mereka miliki, tidaak dapat disangkali bahwa hal ini akan menjadi rumah produksi pendapatan ekonomi yang besar juga bagi masyarakat Desa. Dengan membuka objek wisata untuk umum, maka akan membuka lapangan pekerjaan untuk masyarakat. Dapat di analogikan seperti memecahkan masalah pariwisata tapi memperoleh hasil dengan pemecahan masalah ekonomi. Oleh karena itu sangat diharapkan responsifitas dari perangkat Desa sebagai pihak pemerintah untuk melihat potensi wilayah yang dapat mendongkrak ekonomi dan pendapatan Desa.

Gambar 1.1 beberapa objek wisata yang

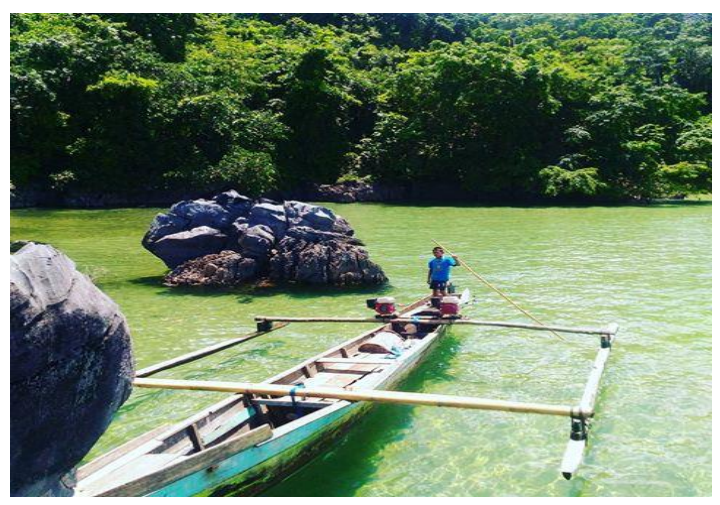

kurang mendapat perhatian dari pemerintah.

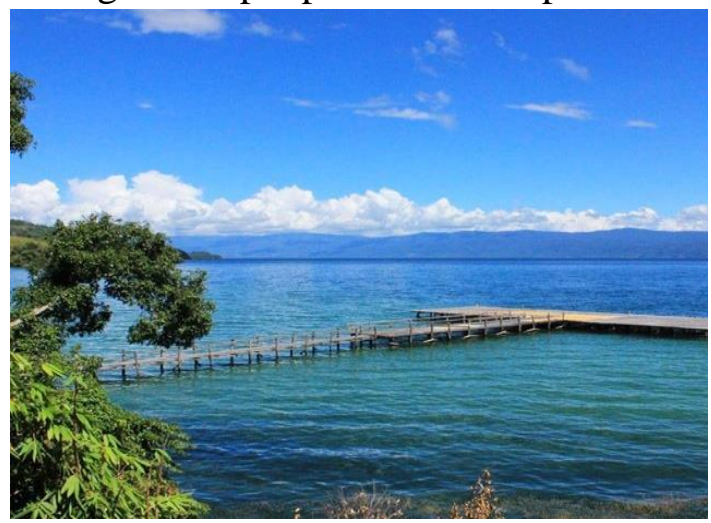

\section{TEORI}

\section{Desa}

Menurut Paul H Landis, Desa adalah suatu wilayah yang jumlah penduduknya kurang dari 2.500 jiwa dengan ciri-ciri sebagai berikut.

$\checkmark$ Mempunyai pergaulan hidup yang saling kenal mengenal antara ribuan jiwa.

$\checkmark$ Ada pertalian perasaan yang sama tentang kesukuan terhadap kebiasaan.

$\checkmark$ Cara berusaha/ekonomi adalah agraris yang paling umum yang sangat dipengaruhi alam sekitar seperti iklim, keadaan alam, kekayaan alam, sedangkan pekerjaan yang bukan agraris adalah bersifat sambilan.

Sedangkan menurut UU No 6 Tahun 2014, Desa dan Desa adat yang disebut dengan nama lain, selanjutnya disebut Desa, adalah masyarakat hukum yang memiliki batas wilayah yang berwenang untuk mengatur dan mengurus urusan pemerintahan, kepentingan masyarakat setempat berdasarkan prakarsa masyarakat, hak asal usul, dan atau hak tradisional yang diakui dan dihormati dalam Sistem pemerintahan Negara Kesatuan Republik Indonesia.

\section{Pemerintah}

Menurut $\mathrm{H}$ Muhammad Rohidin Pranadja dalam bukunya yang berjudul "Hubungan Antara Instansi Pemerintah", gagasan pemerintah menjelaskan bahwa "istilah ini berasal dari pemerintah kata perintah, yang berarti kata-kata yang bermaksud disuruh melakukan sesuatu, 
sesuatu harus dilakukan. Pemerintah adalah orang, badan atau aparat dihapus atau memberi perintah". (Pranadja, 2003:24).

Secara umum, pemerintah adalah organisasi yang memiliki kekuasaan untuk membuat dan menetapkan hukum serta Undang-Undang di wilayah tertentu. Pemerintah Desa atau yang diesbut juga Pemdes adalah Lembaga pemerintah yang bertugas mengelola wilayah tingkat Desa.

\section{Otonomi Daerah}

Indonesia merupakan salah satu Negara yang memakai suatu sistem otonomi Daerah dalam pelaksanaan pemerintahannya. Awalnya otonomi daerah dimulai sejak Tahun 1999 yang tujuannya untuk mempermudah urusan penyelenggaraan Negara.

Menurut Vincent Lemius, otonomi daerah adalah suatu kebebasan atau kewenangan dalam membuat suatu keputusan politik maupun administrasi yang sesuai dengan yang ada di dalam peraturan perundang-undangan. Di dalam suatu otonomi Daerah terdapat sebuah kewenangan yang dimiliki oleh suatu pemerintah Daerah dalam menentukan apa yang menjadi suatu kebutuhan daerahnya namun kebutuhan daerah yang lain masih senantiasa harus disesuaikan dengan suatu kepentingan nasional sebagaimana diatur peraturan perundang-undangan yang lebih tinggi.

\section{Pariwisata}

Menurut Undang-Undang Nomor 10 Tahun 2009, pariwisata ialah berbagai macam kegiatan wisata dan di dukung berbagai fasilitas serta layanan yang disediakan oleh masyarakat, pengusaha, pemerintah dan pemerintag daerah.

Sedangkan menurut World Tourism Organization (WTO), pariwisata merupakan suatu kegiatan manusia yang melakukan perjalanan ke dan tinggal di daerah tujuan diluar lingkungan kesehariannya. Ahli lain yang mengutarakan pendapatnya mengenai pariwisata adalah Robert MClntosh. Ia mengatakan bahwa pariwisata merupakan gabungan dari interaksi antara pemerintah selaku tuan rumah pariwisata, bisnis dan wisatawan.

\section{METODE PENELITIAN}

Penelitian ini menggunakan metode kualitatif dengan menggunakan study kasus. Peneliti memilih lokasi penelitian di Desa Dulumai, Kecamatan Pamona Puselemba, Kabupaten Poso, propinsi Sulawesi Tengah. Sebagai perbandingan keberhasilan pembangunan, peneliti juga mengambil lokasi penelitian di Desa Leboni, Kecamatan pamona Puselemba, kabupaten Poso, Propinsi Sulawesi Tengah. Pemilihan Lokasi pada kedua Desa ini berdasarkan pertimbangan bahwa kedua Desa tersebut sama-sama memperoleh Dana Desa 2017. Penelitian dilakukan dengan melakukan observasi secara langsunguntuk memperoleh bukti nyata dari hasil penelitian nantinya. Selain itu peneliti juga melakukan proses wawancara dengan masyarakat dan perangkat Desa

Lingkup penelitian ini adalah penggunaan Dana Desa yang berfokus pada program prioritas pembangunan poin pertama yaitu Produk Unggulan Kawasan Pedesaan di bidang Pariwisata. Metode pengumpulan data selain dengan wawancara, dilakukan juga melalui dokumentasi.

Selanjutnya, peneliti melakukan pengkajian lalu analisis data berdasarkan hasil perolehan dari wawancara dan observasi di lapangan.

\section{PEMBAHASAN HASIL PENELITIAN}

Peneliti melakukan wawancara dengan beberapa pihak termasuk masyarakat. Berdasarkan hasil wawancara yang dilakukan oleh peneliti yang berlokasi di Desa Dulumai, diperoleh beberapa informasi. Hal yang paling penting adalah aparat Desa masih kurang memahami isi dari Undang-Undang Nomor no 6 tahun 2014 tentang Desa. Dapat dibayangkan jika memahami saja masih sulit, maka pemerintah Desa sendiri pasti masih akan 
kesuliatan dalam proses implementasi Undang-Undang tersebut.

Pariwisata merupakan sektor yang sangat berperan besar dalam menunjang perekonomian di Indonesia. Melalui sektor pariwisata, sektor-sektor lainnya diyakini akan terdorong dan mengalami pertumbuhan. Dibandingkan dengan NegaraNegara ASEAN lainnya, Indonesia memiliki potensi wisata yang lebih besar. Setiap daerah di Indonesia memiliki lebih dari satu situs dan potensi wisata yang bisa dikembangkan. Sayangnya kita belum bisa mengoptimalkannya.

Di era yang semakin maju semakin banyak pula cara dan strategi untuk mengangkat potensi wisata di suatu daerah. Masing-masing daerah memiliki kekhasan atau penonjolan karakteristik alam maupun sosio-kultural dan aspek lainnya. Desa memiliki segudang potensi yang bisa diangkat menjadi komoditas dan dipoles dengan Manajemen Strategi yang tepat untuk menjadi Desa wisata. Strategi apapun membutuhkan dukungan pembangunan infrastruktur yang memadai. Sehingga muncul keyakinan bahwa pengembangan wisata kembali menjadi penyumbang devisa terbesar ketiga bagi Negeri Ini.

Karena itu, untuk terciptanya hasil yang optimal dari pengembangan produk unggulan kawasan pedesaan khususnya di bidang pariwisata yang belu berjalan di Desa Dulumai ini, maka perlu diperhatikan upayaupaya peningkatan sektor wisata sebagai berikut.

a) Pembangunan infrastruktur dan jaringan informasi. Kelemahan pariwisata kita di Indonesia adalah terletak pada buruknya infrastruktur dan jaringan informasi. Seperti contoh beberapa pariwisata di Desa Dulumai yang terlihat pada gambar sebelumnya yang kurang mendapat perhatian dari pemerintah. Akses untuk menuju ke tempat wisata tersebut harus melalui medan yang sulit dan masih harus dilanjutkan dengan naik perahu yang keamanannya kurang menjamin. Hal ini menjadi pertimbangan yang sangat besar bagi wisatawan untuk mengunjungi lokasi pariwisata tersebut. Selain itu, minimnya informasi mengenai tempat-tempat wisata tersebut menjadikannya kurang terekspos luas. Di Zaman sekarang ini, pemerintah seharusnya dapat lebih mudah untuk mempromosikan potensi wisata daerah melalui internet. Akan tetapi, potensi wisata di Desa Dulumai ini sangat sulit untuk ditemukan bahkan dalam situs pencarian di Internet.

b) Kesadaran kolektif pentingnya sektor pariwisata. Alasan utama upaya meningkatkan sektor pariwisata adalah untuk meningkatkan sektor ekonomi. Sehingga perlu membangun kesadaran kolektif dari seluruh lapisan masyarakat dalam hal ini masyarakat Desa. Dengan adanya koordinasi dari masyarakat Desa maka pengembangan daerah wisata juga akan lebih mudah.

c) Memberikan Pelatihan bagi masyarakat Desa dan Pemerintah Desa mengenai Wawasan sektor pariwisata. Mengingat bahwa Kabupaten Poso sudah tertanam dibenak masyarakat Indonesia sebagai daerah konflik, maka perlu adanya pelatihan kepada masyarakat dan pemerintah Desa mengenai Strategi untuk menghadapi hal tersebut. Wisatawan yang berkunjung akan lebih merasa aman dan nyaman jika pemerintah Desa dan masyarakat mampu mengatasi rasa kekhawatiran wisatawan dengan pelayanan yang nyaman dan baik pula. Misalnya dengan menggunakan kebudayaan lokal desa sebagai media untuk memberikan rasa aman dan nyaman bagi pengunjung. Dengan adanya pelatihan, masyarakat tidak akan bingung dalam berkomunikasi, menyikapi dan melayani para wisatawan. Hal ini tentunya akan memberikan nilai tambah bagi wisatawan yang berkunjung.

Sangat besar harapan pemerintah bahwa Dana Desa yang di turunkan tidak hanya digunakan untuk hal yang bukan pada tempatnya tetapi benar-benar dimanfaatkan untuk kesejahteraan bersama dalam rangka mewujudkan masyarakat Madani. 


\section{KESIMPULAN}

Produk Unggulan Kawasan Pedesaan khususnya pada sektor pariwisata yang merupakan salah satu program prioritas penggunaan Dana Desa Tahun 2017, diharapkan mampu mendongkrak perekonomian dan pembangunan masyarakat Indonesia. Desa Dulumai merupakan Desa yang memiliki potensi yang sangat besar untuk menjadi Desa Wisata seperti DesaDesa tetangga lainnya. Desa wisata dimaknai sebagai suatu bentuk integrasi antara atraksi, akomodasi, dan fasilitas pendukung yang disajikan dalam suatu struktur kehidupan masyarakat yang menyatu dengan tata cara dan tradisi yang berlaku di suatu Desa.

Akan tetapi, menjadi pertanyaan besar mengapa pemerintah Desa tidak menjadikan pariwisata sebagai Produk Unggulan Kawasan Pedesaan Desa Dulumai. Melalui penelitian ini, maka dapat diketahui bahwa pemerintah kurang paham mengenai pengolahan dan pengembangan daerah wisata itu sendiri serta bagaimana dari implementasi UU Desa dan penggunaan Dana Desa tersebut.

Hal lain yang mendorong pemerintah kurang bersimpati untuk pengembangan daerah wisata adalah kurangnya perhatian dari pemerintah Daerah sendiri dengan sektor wisata. Pemerintah Desa mengakui kurangnya penghargaan dari pemerintah Daerah untuk daerah yang berhasil mengembangkan daerah wisatanya merupakan salah satu faktor kurangnya perhatian pemerintah desa di sektor swasta. Seperti pelaksanaan festival untuk mengeksplor pariwisata yang hanya diadakan satu kali dalam setahun, itu pun tidak dilaksanakan maksimal.

Jika pemerintah Desa bisa mengembangkan potensi wisata tersebut, Desa Dulumai bukan hanya memiliki Sumber Daya Wisata yang menarik tapi juga memiliki Kebudayaan yang menarik. Seperti menjamu tamu untuk makan bersama di balai Desa setiap kali kedatangan tamu dengan menciptakan suasana kekeluargaan yang hangat dan kebudayaan ini hanya bisa ditemui di Desa Dulumai.

Melihat masih banyaknya kekurangan dari implementasi Dana Desa tersebut, maka Pemerintah selaku pemerintah daerah perlu lebih mengoptimalkan fungsi pengawasan serta bimbingan kepada pemerinntah Desa agar tidak adanya kekeliruan baik dalam hal implementasi Dana Desa maupun teknik memilah program yang tepat untuk dilaksanakan. Disamping itu, pendampingan pemerintah Daerah sangat dibutuhkan mengingat pemerintah daerah sendiri yang kurang paham dan masih ragu untuk mengurus Dana Desa. Dengan adanya pembimbingan serta pengawasan yang baik, maka diyakini penggunaan Dana Desa akan tepat sasaran dan tidak keliru. Sehingga mampu memberikan dampak yang baik untuk kesejahteraan masyarakat Desa.

\section{DAFTAR PUSTAKA}

Undang-Undang Nomor 6 Tahun 2014 Tentang Desa

Direktorat Jenderal Pembangunan dan Pemberdayaan Masyarakat Desa. 2015. Pengembangan

Desa. Jakarta Selatan

Sutoro Eko. 2014. Desa Membangun Indonesia. Yogyakarta.

Mahbub Janidi, dkk. 2015. Buku Desa. Komisi Informasi Provinsi Jawa Timur

Kementrian Keuangan Republik Indonesia. 2017. Kebijakan Pengalokasian dan Penyaluran

Dana Desa Tahun 2017. Jakarta

Kementrian Keuangan Republik Indonesia. 2017. Buku Pintar Dana Desa. Jakarta 